\title{
BMJ Impact of the economic crisis on open children's health in Catalonia: a before-after approach
}

\author{
Luis Rajmil, ${ }^{1,2,3}$ Antonia Medina-Bustos, ${ }^{4}$ María-José Fernández de Sanmamed, ${ }^{5}$ \\ Anna Mompart-Penina ${ }^{4}$
}

To cite: Rajmil L, MedinaBustos A, Fernández de Sanmamed M-J, et al. Impact of the economic crisis on children's health in Catalonia: a before-after approach. BMJ Open 2013;3:e003286. doi:10.1136/bmjopen-2013003286

- Prepublication history for this paper is available online. To view these files please visit the journal online (http://dx.doi.org/10.1136/ bmjopen-2013-003286).

Received 22 May 2013 Revised 28 June 2013 Accepted 15 July 2013

${ }^{1}$ Agència de Qualitat i Avaluació Sanitàries (AQuAS), Barcelona, Spain

${ }^{2}$ IMIM (Hospital del Mar Medical Research Institute), Barcelona, Spain ${ }^{3}$ CIBER de Epidemiología y Salud Pública, Barcelona, Spain

${ }^{4}$ Servei del Pla de Salut, Direcció General de Regulació Planificació i Recursos Sanitaris, Departament de Salut Generalitat de Catalunya, Barcelona, Spain ${ }^{5}$ Centre d'Atenció Primària (CAP) Horta 7D, Institut Català de la Salut, Barcelona, Spain

\section{Correspondence to}

Dr Luis Rajmil;

Irajmil@imim.es/

Irajmil@gencat.cat,

http://www.aatrm.net

\section{ABSTRACT}

Objectives: To analyse changes in the family living conditions of children in Catalonia between 2006 and the 2010-2012 period, and to study associations between these changes and health outcomes.

Design: A before-after analysis of two cross-sectional surveys.

Setting: Population younger than 15 years of age from Catalonia, Spain.

Participants: Representative samples of children in the 2006 Catalan Health Survey (ESCA), baseline, before the crisis; $\mathrm{n}=2200$ ) and the first four waves of ESCA 2010-2012 (after start of the crisis, $n=1967$ ).

Main outcome measures: Overweight/obesity, health behaviour, mental health and health-related quality of life (HRQOL). Logistic regression and multiple linear regression models were used to analyse the influence of changes in family conditions on outcome measures, including interaction terms to describe the potential influence of the study period on the results.

Results: The percentage of unemployed families rose from $9.1 \%$ (2006) to $20.6 \%$ (2010-2012), with inequalities by level of education. Overweight/obesity increased from $18.4 \%(95 \% \mathrm{Cl} 16.5 \%$ to $20.4 \%)$ to $26.9 \%(24.6 \%$ to $29.2 \%)$ in $2010-2012$, and inequalities related to maternal education and employment status persisted. Eating habits have improved in 2010-2012 in disadvantaged families (ie, junk food consumption improved in families with a maternal primary education level; beta $(B)=2.85 ; 0.83$ to 4.88 , for the survey interaction by primary education level). An improvement in HRQOL was found in the second survey ( $B=6.07 ; 4.15$ to 7.99 ), although children whose mothers had a primary education showed poorer HRQOL scores in this survey than in 2006 ( $\mathrm{B}=-4.14 ;-7.17$ to -1.12 ).

Conclusions: Although some health-related behaviour improved during the study period, childhood obesity increased and inequalities in HRQOL appeared. Policy measures that fight against these inequalities should be urgently implemented to avoid their negative impact on the health of future generations of Catalans.

\section{ARTICLE SUMMARY}

Article focus

- The current economic and financial crises have worsened the living conditions of children in Catalonia, Spain, comparing the 2006 and 2010 2012 periods.

- Worsening of socioeconomic conditions associated with the crisis would more specifically affect the children of disadvantaged families.

- An increase in unhealthy behaviour and in the inequalities related to obesity and mental health could also be expected.

\section{Key messages}

- An increase in social inequalities has occurred in Catalonia, with higher levels of unemployment in families with lower levels of education.

- Although some health-related behaviour improved in the overall population in the period studied, disparities in childhood obesity remained and inequalities in health-related quality of life appeared according to the level of education.

Strengths and limitations of this study

- The content of the questionnaire was similar in both surveys; the data are consistent and have proven to be valid and useful to analyse the impact of the crisis on child health.

- It is not possible to directly attribute changes found in the present study to the impact of the crisis. Nevertheless, it is clear that children's living conditions have worsened in this 6-year study period, and this change has had an impact on their health.

- The sample in the 2010-2012 Catalan Health Interview Survey was slightly younger and with a higher maternal education level than the 2006 sample. However, these differences may mask even greater disparities.

\section{INTRODUCTION}

The current economic and financial crisis has affected the whole of Europe's economy, although the impact in each country depends on the starting point, mechanisms of social protection and social transfers and the measures governments have adopted to fight the crisis. 
A review of the evidence related to the impact of the crisis on the health of young people (15-24 years) has found increasing levels of ill health, particularly with regard to sexually transmitted disease and substance abuse, and a general decline in the use of healthcare services. ${ }^{1} \mathrm{~A}$ comprehensive review of the impact on neonatal outcomes has reported inconclusive results regarding low birthweight and neonatal mortality. ${ }^{2}$ Some positive aspects have also been described. ${ }^{3}$ A decrease in environmental pollution and traffic accidents is expected, and the crisis occurring in the 1990s had a positive impact on health in the Nordic countries. ${ }^{4}$ In the current crisis, a recent report from the UK has revealed a significant impact on the eating habits of children from families in poverty. ${ }^{5}$ In the USA, an association was reported between economic recession measured by unemployment rates and head injuries due to violence against children. ${ }^{6}$

In Spain, the government has significantly cut public health and education budgets and has also reduced aid to families with children in the lower socioeconomic strata. Spain's UNICEF report has analysed the growth of poverty in children, which is higher than in the remainder of the population. ${ }^{7}$ Another recent study emphasises that the crisis has manifested in a particularly acute form in households with children, causing a greater decline and social exclusion than in households with no children. ${ }^{8}$ However, there are little data comparing children's health before and after the crisis started.

In Catalonia, a northeastern region of Spain, the Catalan Health Survey (Enquesta de Salut de Catalunya, ESCA) ${ }^{9}$ has provided the opportunity to analyse the effects of the crisis on the health of our children. The objectives of this study were to analyse changes in the family life conditions and socioeconomic status (SES) of children (0-14 years) in Catalonia between 2006 and the 2010-2012 period, and to study the association of these changes with modifications in health-related behaviour, physical and mental health and health-related quality of life (HRQOL). The main hypothesis was that worsening of socioeconomic conditions associated with the crisis would more specifically affect the children of disadvantaged families. An increase in unhealthy behaviour and in inequalities related to obesity and mental health would also be expected. In contrast, no differences would be expected in HRQOL between years 2006 and 2010-2012.

\section{METHODS}

The study design is a before-after analysis of data from two separate cross-sectional representative samples of children in the 2006 ESCA survey (baseline, before the crisis) and the first four waves of ESCA 2010-2012 (after the start of the crisis). The ESCA Statistical Plan is a part of the Autonomous Government of Catalonia and is regulated by Decree 467/2004 of 28 December, according to which the performance statistics have been approved yearly since 2005. It is an official statistic, so selected individuals are likely to participate in the survey, which meets all the regulatory requirements, in particular confidentiality of the data obtained. ESCA is conducted by the Department of Health of the Government of Catalonia. All analyses using ESCA data must be anonymised so that no individual information is identifiable.

\section{Sampling selection and procedures}

ESCA 2006 was undertaken from December 2005 to July 2006. ${ }^{10}$ The survey consisted of a multistage probability sample representative of the non-institutionalised population, stratified by age, sex and municipal size for each territorial health government within Catalonia. ${ }^{11}$ The sample size of children 14 years of age and younger from ESCA 2006 was established at 2200 individuals. The sample was stratified according to the size of the municipalities, and the final stage consisted in the random selection of individuals from the Catalonian population register for each selected municipality. Sixty-five per cent of interviews were carried out in the selected individuals, as against $22 \%$ in the first substitute. Data for children $\leq 14$ years old were obtained from proxy respondents (mainly mothers) by means of a structured interview.

Between the second half of 2010 and the first half of 2012, the fieldwork was performed for the first four waves of the continuous ESCA 2010-2012. ${ }^{9}$ The results are representative of the whole of Catalonia. Sample size was estimated at approximately 2500 interviews twice yearly, of which 1967 were addressed to the population $\leq 14$ years old after the first four waves. ESCA 2010-2012 was conducted following the same method of administration as the survey in 2006. In this second survey, $68 \%$ of proxy respondent interviews for children $\leq 14$ years were carried out in the selected individuals, as against $17 \%$ in the first substitute. Home interviews were conducted by trained interviewers in both periods.

\section{Measures}

Restriction of activities in the previous 12 months (yes/ no) and reports of chronic conditions (no chronic conditions/one/more than one) were collected. Overweight/ obesity was based on the body mass index (BMI), calculated through the parents' reports of weight and height, and using specific cut-off points for Spain. ${ }^{12}$

Mental health was assessed using the parents' version of the Strengths and Difficulties Questionnaire (SDQ).$^{13} 14$ The sum of the scores on four scales related to negative aspects yields the Total Difficulties Score (TDS-SDQ), with a range of $0-40$. The higher the TDS-SDQ score, the poorer is the child's mental health. Evaluation of HRQOL used the shortest parent-reported version of the KIDSCREEN (KS) instrument, the KS-10 Index. ${ }^{15}{ }^{16}$ In the present study, KS-10 was computed in keeping with the version used in the European Eurobarometer study. ${ }^{17}$ The modified KS-10 scores were transformed to a scale of $0-100$ : the higher the score, the better the HRQOL. 
The Junk food consumption (4 items), Physical activity (6 items) and Risk behaviour (5 items) scales came from the parent version of the Child Health and Illness Profile. $^{18} 19$ The mean scores on these scales were standardised to a mean of 50 and $1 \mathrm{SD}=10$, according to the ESCA 2006 sample. Higher scores reflect less junk food consumption and risk behaviour, and greater physical activity. The number of times per week a child had breakfast at home was collected in a single question with a four-point Likert scale (recoded as never vs the remaining categories). The mean number of hours a day the child spent viewing TV, computers, etc was collected as an indicator of sedentary behaviour. Physical activity, risk behaviour and KS-10 results were collected in children 6 years and older; SDQ included children from 4 years onward, time spent on screen, never having breakfast and junk food consumption collected from 3 years onward, and BMI was collected in children 2 years and older.

Sociodemographic variables included age, sex and family maternal level of education as a measure of SES. Educational level referred to the highest level of schooling completed by the mother, categorised into three groups: primary school or less, secondary school and university degree. The family structure (single-parent family vs two-parent family), and child's origin (native vs immigrant), when both parents and/or the child were born in a developing country, were also included. Family employment status (unemployed) was collected and coded as a dichotomous variable (unemployed vs employed, student, etc) if at least one parent reported current unemployed status.

\section{Statistical analysis}

The percentage (or mean) and 95\% CI was computed for each variable analysed according to the sociodemographic characteristics and study period.

The association between changes in family socioeconomic conditions and health-related factors, mental health and HRQOL was analysed by means of logistic regression or multiple linear regression models, depending on the nature of the dependent variable. All models included the study period as an independent variable (2006=0 and 2010-2012=1). Interaction terms between SES, health-related factors and study period were also explored to consider the possibility of changes over time in the effect of SES and health-related factors on the outcome measures. Analyses were carried out using Stata V.10.0, considering the complex sampling design by applying specific weights for each survey in the estimation of coefficients and variance.

\section{RESULTS}

The characteristics of the samples in ESCA 2006 and 2010 2012 are shown in table 1 . The mean age was 7.9 years (SD $0.08)$ in 2006 and 6.9 years $(0.08)$ in 2010-2012 $(\mathrm{p}<0.01)$. ESCA 2006 showed a lower percentage of children from families with a maternal university degree $(22.8 \%$ vs $29.5 \%$, $\mathrm{p}<0.01)$, families of immigrant origin $(9.5 \%$ vs $20.1 \%)$ and unemployed families $(9.1 \%$ vs $20.6 \%, \mathrm{p}<0.01)$.

Table 2 shows changes in unemployment according to sociodemographic variables. The percentages of unemployed families have increased in ESCA 2010-2012 (9.7\%; $8.2 \%$ to $11.2 \%$ in ESCA 2006 and $20.7 \%$; $18.8 \%$

Table 1 Sociodemographic characteristics of the sample

\begin{tabular}{|c|c|c|c|c|c|}
\hline & \multicolumn{2}{|l|}{2006} & \multicolumn{2}{|c|}{ 2010-2012 } & \multirow[b]{2}{*}{ p Value } \\
\hline & $\overline{\mathbf{N}}$ & Per cent & $\overline{\mathbf{N}}$ & Per cent & \\
\hline \multicolumn{6}{|l|}{ Sex } \\
\hline Girls & 1064 & 48.5 & 970 & 49.3 & 0.55 \\
\hline \multicolumn{6}{|l|}{ Age } \\
\hline Mean (SD) & 2200 & $7.85(0.08)$ & 1967 & $6.93(0.08)$ & $<0.01$ \\
\hline $0-4$ years & 544 & 25.1 & 552 & 28.1 & \\
\hline $5-9$ years & 842 & 38.5 & 899 & 45.7 & \\
\hline 10-14 years & 814 & 36.5 & 516 & 26.2 & $<0.01$ \\
\hline \multicolumn{6}{|l|}{ Maternal level of education } \\
\hline Primary & 473 & 20.0 & 275 & 14.0 & \\
\hline Secondary & 1227 & 57.2 & 1112 & 56.5 & \\
\hline University degree & 493 & 22.8 & 580 & 29.5 & $<0.01$ \\
\hline \multicolumn{6}{|l|}{ Type of family } \\
\hline Single parent & 199 & 9.0 & 193 & 9.8 & 0.39 \\
\hline \multicolumn{6}{|l|}{ Migration status } \\
\hline Immigrant & 209 & 9.5 & 395 & 20.1 & $<0.01$ \\
\hline \multicolumn{6}{|l|}{ Employment status } \\
\hline At least one unemployed & 161 & 8.6 & 303 & 15.5 & \\
\hline Both members unemployed & 23 & 0.5 & 100 & 5.1 & $<0.01$ \\
\hline
\end{tabular}

ESCA 2006 and 2010-2012 (unweighted data).

Missing values 2006: level of education (7), unemployed (56); 2010-2012: type of family (3), unemployed (10). Source: Catalan Health Department, Catalan Health Interview Survey. 
Table 2 Changes in family employment status according to sociodemographic characteristics

\begin{tabular}{|c|c|c|c|c|}
\hline & \multicolumn{2}{|l|}{2006} & \multicolumn{2}{|l|}{ 2010-2012 } \\
\hline & Percentage of unemployed & $95 \% \mathrm{Cl}$ & Percentage of unemployed & $95 \% \mathrm{Cl}$ \\
\hline Total & 9.7 & 8.2 to 11.2 & 20.7 & 18.8 to 22.7 \\
\hline \multicolumn{5}{|l|}{ Age (years) } \\
\hline $0-4$ & 11.6 & 8.2 to 14.9 & 22.1 & 18.4 to 25.8 \\
\hline $5-9$ & 8.5 & 6.2 to 10.7 & 19.6 & 16.8 to 22.4 \\
\hline $10-14$ & 9.7 & 7.2 to 12.3 & 20.4 & 16.6 to 24.2 \\
\hline \multicolumn{5}{|l|}{ Sex } \\
\hline Girl & 9.7 & 7.5 to 11.8 & 22.6 & 19.6 to 25.5 \\
\hline Boy & 9.8 & 7.6 to 11.9 & 19.0 & 16.4 to 21.7 \\
\hline \multicolumn{5}{|l|}{ Level of education } \\
\hline Primary & 12.7 & 9.0 to 16.4 & 36.3 & 30.0 to 42.6 \\
\hline Secondary & 11.4 & 9.2 to 13.5 & 22.2 & 19.5 to 25.0 \\
\hline University degree & 3.0 & 1.4 to 4.7 & 11.6 & 8.6 to 14.5 \\
\hline \multicolumn{5}{|l|}{ Type of family } \\
\hline Biparental & 9.6 & 8.0 to 11.1 & 19.9 & 17.8 to 21.9 \\
\hline Monoparental & 11.6 & 5.6 to 17.6 & 27.8 & 20.9 to 34.7 \\
\hline
\end{tabular}

to $22.7 \%$ in ESCA 2010-2012). This change was particularly important in families with a maternal primary education $(12.7 \%$; $9.0 \%$ to $16.4 \%$ in 2006 to $36.3 \% ; 30.0 \%$ to $42.6 \%$ ).

The results of health behaviour, obesity, HRQOL and mental health, according to maternal education level and family employment status, are summarised in table 3 . The mean time spent on screen was lower in 2010-2012 (2 in 2006 vs 1.4 in 2010-2012). The prevalence of overweight/ obesity was $18.5 \%$ (16.5\% to $20.4 \%$ ) in 2006 and $27.0 \%$ $(24.6 \%$ to $29.2 \%)$ in $2010-2012$. Obesity in children increased from $23.2 \%$ ( $18.8 \%$ to $27.6 \%$ ) to $35.5 \%$ (28.6\% to $42.3 \%$ ) in families with a maternal primary education, and from $13.1 \%(9.5 \%$ to $16.5 \%)$ to $21.4 \%(17.4 \%$ to $25.3 \%$ ) in those with a maternal university degree. A higher percentage of obesity was also found in the last survey for children of unemployed families in 2010-2012 $(33.8 \%$; $28.4 \%$ to $39.3 \%)$. KS-10 showed higher mean scores (better) in 2010-2012 (85.4; 84.4 to 86.0) compared with 2006 (81.0; 80.7 to 81.7 ), but lower scores in children with a maternal primary education $(82.4 ; 80.6$ to 84.1$)$ and unemployed families $(83.34 ; 81.89$ to 84.9$)$. Scores on TDS-SDQ were slightly lower (better) in 2010-2012, but differences have remained in relation to maternal education and employment status.

The results of multivariate analysis of health behaviour are shown in table 4. Differences by maternal education level were found for junk food consumption and time spent on screen, and by employment status in never having breakfast. Junk food consumption improved in 2010-2012 in families with a maternal primary education level (beta $(\mathrm{B})=2.85 ; 0.83$ to 4.88 , for the interaction term of the survey by primary education level) and never having breakfast decreased in unemployed families in 2010-2012 (OR 0.33; 0.13 to 0.80 ; for survey by employment status).
The likelihood of overweight/obesity increased in 2010-2012 (OR 1.81; 1.18 to 2.78; table 5). Several factors were associated with overweight/obesity in the overall sample, whereas never having breakfast before leaving home (OR 2.65; 1.11 to 6.31 ) was associated with increasing the likelihood of obesity in 2010-2012. An improvement in HRQOL was found in 2010-2012 ( $\mathrm{B}=6.07$; 4.15 to 7.99), although children with a maternal primary education showed lower (worse) scores on the KS-10 Index in this survey $(\mathrm{B}=-4.14 ;-7.17$ to -1.12$)$. Differences in mental health were found in the overall sample according to the level of education and in single-parent families, while differences in TDS-SDQ scores according to maternal education decreased in 2010-2012.

\section{DISCUSSION}

This study shows that there has been an increase in social inequalities in Catalonia with higher levels of unemployment in families with a lower level of education. Certain behaviour patterns improved in disadvantaged families in 2010-2012, such as junk food consumption and having breakfast before leaving home. Nevertheless, an alarming increase in overweight/ obesity in the total population was found during the study period. HRQOL was better in the second survey. Nevertheless, disparities appeared, with lower HRQOL scores in children from families with a maternal primary education. Inequality has remained in mental health.

Although it is not possible to directly attribute changes found in the present study to the impact of the crisis, it is clear that children's living conditions have worsened in this 6-year study period, and this change has had an impact on their health.

According to the UNICEF report, child poverty increased in Spain by $53 \%$ between 2007 and $2010 .^{7}$ 
This factor is associated with a reduction in family expenditure, changes in food habits, loss of housing and rising inequality. In Catalonia, the Living Conditions
Survey $^{20}$ and the Household Budget Continuous Survey ${ }^{21}$ provide data on family living conditions and the risk of poverty. The percentage of children 16 years

Table 3 Health behaviours and health status characteristics by maternal level of education and family employment status

\begin{tabular}{|c|c|c|c|c|}
\hline & \multicolumn{2}{|l|}{2006} & \multicolumn{2}{|c|}{ 2010-2012 } \\
\hline & Per cent & $95 \% \mathrm{Cl}$ & Per cent & $95 \% \mathrm{Cl}$ \\
\hline \multicolumn{5}{|l|}{ Health behaviours } \\
\hline Never having breakfast & 4.9 & 3.8 to 6.0 & 5.4 & 4.8 to 6.7 \\
\hline \multicolumn{5}{|l|}{ Level of education } \\
\hline Primary & 5.9 & 3.4 to 8.4 & 7.7 & 3.6 to 11.8 \\
\hline Secondary & 5.1 & 3.6 to 6.7 & 6.4 & 4.6 to 8.1 \\
\hline University degree & 3.5 & 1.5 to 5.5 & 2.7 & 1.0 to 4.4 \\
\hline \multicolumn{5}{|l|}{ Employment status } \\
\hline Employed & 4.3 & 3.2 to 5.5 & 5.6 & 4.2 to 7.1 \\
\hline \multirow[t]{2}{*}{ Unemployed } & 8.8 & 2.3 to 13.3 & 4.4 & 2.0 to 6.9 \\
\hline & Mean & $95 \% \mathrm{Cl}$ & Mean & $95 \% \mathrm{Cl}$ \\
\hline Time spent on screen (h/day) & 2.03 & 1.98 to 2.07 & 1.41 & 1.35 to 1.47 \\
\hline \multicolumn{5}{|l|}{ Level of education } \\
\hline Primary & 2.16 & 2.08 to 2.25 & 1.73 & 1.5 to 1.95 \\
\hline Secondary & 2.08 & 2.01 to 2.14 & 1.53 & 1.45 to 1.6 \\
\hline University degree & 1.77 & 1.68 to 1.87 & 1.07 & 0.98 to 1.15 \\
\hline \multicolumn{5}{|l|}{ Employment status } \\
\hline Employed & 2.01 & 1.96 to 2.06 & 1.36 & 1.29 to 1.43 \\
\hline Unemployed & 2.06 & 1.92 to 2.21 & 1.62 & 1.48 to 1.76 \\
\hline Junk food consumption & 50.24 & 49.74 to 50.74 & 52.34 & 51.92 to 52.76 \\
\hline \multicolumn{5}{|l|}{ Level of education } \\
\hline Primary & 47.46 & 46.36 to 48.55 & 50.14 & 49.0 to 51.27 \\
\hline Secondary & 50.21 & 49.53 to 50.89 & 52.13 & 51.57 to 52.68 \\
\hline University degree & 52.79 & 51.91 to 53.97 & 53.68 & 52.93 to 54.94 \\
\hline \multicolumn{5}{|l|}{ Employment status } \\
\hline Employed & 50.35 & 49.84 to 50.87 & 52.7 & 52.23 to 53.16 \\
\hline Unemployed & 50.25 & 48.41 to 52.01 & 51.04 & 50.06 to 52.02 \\
\hline Physical activity & 50.14 & 49.52 to 50.76 & 48.23 & 47.59 to 48.87 \\
\hline \multicolumn{5}{|l|}{ Level of education } \\
\hline Primary & 50.62 & 49.21 to 52.03 & 46.53 & 44.7 to 48.33 \\
\hline Secondary & 49.74 & 48.94 to 50.54 & 48.16 & 47.33 to 48.99 \\
\hline University degree & 50.81 & 49.44 to 52.19 & 49.18 & 48.0 to 50.37 \\
\hline \multicolumn{5}{|l|}{ Employment status } \\
\hline Employed & 50.26 & 49.61 to 50.92 & 48.23 & 47.62 to 49.04 \\
\hline Unemployed & 48.23 & 46.1 to 50.37 & 47.83 & 46.35 to 49.31 \\
\hline Risk behaviours & 50.52 & 49.93 to 51.12 & 51.74 & 51.19 to 52.29 \\
\hline \multicolumn{5}{|l|}{ Level of education } \\
\hline Primary & 50.37 & 49.25 to 51.48 & 50.91 & 49.48 to 52.34 \\
\hline Secondary & 50.01 & 49.17 to 50.86 & 51.51 & 50.78 to 52.23 \\
\hline University degree & 52.06 & 50.93 to 53.19 & 52.65 & 51.6 to 53.69 \\
\hline \multicolumn{5}{|l|}{ Employment status } \\
\hline Employed & 50.59 & 49.95 to 51.23 & 52.07 & 51.44 to 52.69 \\
\hline Unemployed & 50.44 & 48.59 to 52.3 & 50.5 & 49.31 to 51.7 \\
\hline Health status & Per cent & $95 \% \mathrm{Cl}$ & Per cent & $95 \% \mathrm{Cl}$ \\
\hline Overweight/obesity & 18.49 & 16.5 to 20.4 & 26.96 & 24.6 to 29.2 \\
\hline \multicolumn{5}{|l|}{ Level of education } \\
\hline Primary & 23.15 & 18.75 to 27.55 & 35.46 & 28.64 to 42.29 \\
\hline Secondary & 18.99 & 16.39 to 21.6 & 28.22 & 25.14 to 31.3 \\
\hline University degree & 13.1 & 9.5 to 16.5 & 21.35 & 17.43 to 25.26 \\
\hline \multicolumn{5}{|l|}{ Employment status } \\
\hline Employed & 18.16 & 16.13 to 20.2 & 25.26 & 22.74 to 27.78 \\
\hline Unemployed & 20.58 & 14.19 to 26.96 & 33.8 & 28.35 to 39.25 \\
\hline
\end{tabular}

Continued 
Table 3 Continued



and younger at risk of poverty has increased from $20.6 \%$ in 2005 to $23.7 \%$ in 2010 after social transfers. The population younger than 17 years living in unemployed families has increased from $3.7 \%$ to $11.2 \%$. The percentage of school dropouts decreased from $33 \%$ to $29 \%$ between 2005 and 2010, whereas unemployment in persons aged 16-24 years has increased more than 2.5-fold (15-40\%). ${ }^{22}$ In addition to reinforcing these figures, the results of this study include the impact on physical and mental health and the quality of life.

Some results of the present study, such as improving eating habits in children from disadvantaged families, seem to contradict the great increase in obesity that was found in the study period. It is likely that this improvement has not been sufficient to overcome the negative impact of factors such as resource unavailability on family foods, the ability to cope with stress and increased inequalities in HRQOL. The attributable risk of obesity was $26 \%$ for education level in ESCA 2010-2012. Moreover, in this specific case, which showed a very important social gradient, certain measures taken by the Catalan government, such as restricting the use of food stamps, will increase the risk of inequalities in relation to obesity. These facts support the need for stronger protection mechanisms during the crisis to reduce the effect of deficits in the family and social resources related to healthy child development.

Inequalities in children's mental health were described in Catalonia (ESCA 2006) ${ }^{23}$ and Spain (Spanish Health Survey 2006) ${ }^{24}$ Social inequalities according to maternal education level have persisted with the crisis. However, these previous studies did not report inequalities in the quality of life. This is the first time this inequality has been found in relation to education level and employment status in Catalonia, and it is most likely a result of continuous exposure to stress in the most vulnerable population. The higher average HRQOL scores in the 2010-2012 survey may be related, in part, to the younger age of the second sample.

Some limitations of the study deserve comments. Differences in the characteristics of the sample in the two surveys may have influenced the results. The ESCA 2010-2012 sample was younger and mothers were more educated. The results on the education level reflect true differences in the general population of Catalonia. According to the census data, ${ }^{25}$ the percentage of women with university degrees increased between 2005 and 2010. These changes could be reflected in the better HRQOL found in the overall 2010-2012 sample of the present study, although the figures could also be associated with secular trends. The percentage of unemployed households seems to be underestimated in ESCA 2010-2012: in 11\% of households, all members were unemployed in 2010 according to a previously mentioned survey, ${ }^{22}$ whereas in ESCA 2010-2012 the figure was $5 \%$. These results may underestimate the impact of the crisis on inequalities in children's health. Differences in the percentage of children from immigrant families could be attributed to data collection in 2006, which was less exhaustive with respect to the variable parents' place of birth. For this reason, the results related to this variable should be interpreted with 
Table 4 Multivariate analysis of health behaviours

\begin{tabular}{|c|c|c|c|c|c|c|c|c|c|c|}
\hline & \multicolumn{2}{|c|}{$\begin{array}{l}\text { Junk food } \\
\text { consumption }\end{array}$} & \multicolumn{2}{|c|}{ Physical activity } & \multicolumn{2}{|c|}{ Risk behaviours } & \multicolumn{2}{|c|}{ Time spent on screen } & \multicolumn{2}{|c|}{$\begin{array}{l}\text { Never having } \\
\text { breakfast }\end{array}$} \\
\hline & B & $95 \% \mathrm{Cl}$ & B & $95 \% \mathrm{Cl}$ & B & $95 \% \mathrm{Cl}$ & B & $95 \% \mathrm{Cl}$ & OR & $95 \% \mathrm{Cl}$ \\
\hline \multicolumn{11}{|l|}{ Sex } \\
\hline Boys & Ref & & Ref & & Ref & & Ref & & Ref & \\
\hline Girls & 0.53 & -0.12 to 1.18 & -4.74 & -5.61 to -3.86 & 2.19 & 1.37 to 3.0 & -0.23 & -0.3 to 0.16 & 0.99 & 0.69 to 1.41 \\
\hline Age & -0.3 & -0.4 to -0.21 & 0.07 & -0.09 to 0.24 & 0.03 & -0.12 to 0.19 & 0.09 & 0.08 to 0.1 & 1.14 & 1.08 to 1.21 \\
\hline \multicolumn{11}{|l|}{ Maternal education } \\
\hline Primary & -4.64 & -6.07 to -0.21 & -0.03 & -1.99 to 1.92 & -1.5 & -3.13 to 0.13 & 0.3 & 0.17 to 0.43 & 1.34 & 0.63 to 2.84 \\
\hline Secondary & -2.25 & -3.37 to -1.13 & -0.92 & -2.51 to 0.65 & -1.96 & -3.4 to -0.52 & 0.26 & 0.15 to 0.36 & 1.2 & 0.6 to 2.39 \\
\hline University degree & Ref & & Ref & & Ref & & Ref & & Ref & \\
\hline \multicolumn{11}{|l|}{ Survey } \\
\hline 2006 & Ref & & Ref & & Ref & & Ref & & Ref & \\
\hline 2010-2012 & 0.89 & -0.27 to 2.06 & -1.32 & -3.16 to 0.5 & 0.78 & -0.76 to 2.34 & -0.72 & -0.84 to -0.59 & 0.79 & 0.32 to 1.95 \\
\hline \multicolumn{11}{|l|}{ Employed } \\
\hline Employed & Ref & & Ref & & Ref & & Ref & & Ref & \\
\hline Unemployed & 0.4 & -1.45 to 2.27 & -1.87 & -4.1 to 0.36 & 0.18 & -1.85 to 2.22 & 0.003 & -0.13 to 0.14 & 2.09 & 1.12 to 3.88 \\
\hline \multicolumn{11}{|l|}{ Family type } \\
\hline Biparental & Ref & & Ref & & Ref & & Ref & & Ref & \\
\hline Monoparental & -0.89 & -2.92 to 1.13 & 1.71 & -0.53 to 3.98 & -4.73 & -7.33 to -2.14 & 0.08 & -0.08 to 0.25 & 0.79 & 0.32 to 1.91 \\
\hline \multicolumn{11}{|l|}{ Origin } \\
\hline Native & Ref & & Ref & & Ref & & Ref & & Ref & \\
\hline Immigrant & -3.93 & -5.82 to -2.04 & -0.18 & -2.6 to 2.22 & 1.7 & -0.33 to 3.73 & 0.12 & -0.02 to 0.27 & 1.19 & 0.53 to 2.64 \\
\hline \multicolumn{11}{|l|}{ Interaction terms } \\
\hline Primary education by survey & 2.85 & 0.83 to 4.88 & -1.77 & -4.7 to 1.16 & -0.17 & -2.64 to 2.3 & 0.14 & -0.11 to 0.4 & 2.09 & 0.63 to 6.93 \\
\hline Secondary education by survey & 1.22 & -0.22 to 2.67 & 0.08 & -2.05 to 2.3 & 0.87 & -1.04 to 2.78 & 0.10 & -0.04 to 0.26 & 1.92 & 0.71 to 5.23 \\
\hline Employment by survey & & & & & & & & & 0.33 & 0.13 to 0.8 \\
\hline Origin by survey & & & & & & & 0.23 & 0.002 to 0.45 & 1.05 & 0.37 to 2.94 \\
\hline Family type by survey & 1.82 & -0.55 to 4.2 & -1.85 & -4.78 to 1.08 & 2.77 & -0.35 to 5.9 & -0.005 & -0.26 to 0.25 & 1.46 & 0.37 to 4.45 \\
\hline
\end{tabular}

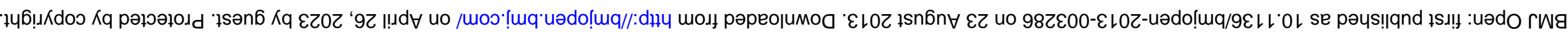


Table 5 Multivariate analysis of health status variables (logistic regression model for overweight/obesity, and linear regression models of KS-10 and SDQ)

\begin{tabular}{|c|c|c|c|c|c|c|}
\hline & \multicolumn{2}{|c|}{ Overweight/obesity } & \multicolumn{2}{|l|}{ KS-10 } & \multicolumn{2}{|c|}{ TDS-SDQ } \\
\hline & $\overline{\text { OR }}$ & $95 \% \mathrm{Cl}$ & B & $95 \% \mathrm{Cl}$ & B & $95 \% \mathrm{Cl}$ \\
\hline \multicolumn{7}{|l|}{ Sex } \\
\hline Boys & Ref & & Ref & & Ref & \\
\hline Girls & 0.88 & 0.73 to 1.06 & 0.67 & -0.26 to 1.62 & -0.91 & -1.27 to -0.55 \\
\hline Age & 0.91 & 0.88 to 0.94 & -0.33 & -0.52 to -0.14 & -0.08 & -0.13 to -0.02 \\
\hline \multicolumn{7}{|l|}{ Maternal education } \\
\hline Primary & 1.80 & 1.16 to 2.80 & 0.29 & -1.81 to 2.41 & 2.28 & 1.52 to 3.03 \\
\hline Secondary & 1.55 & 1.06 to 2.29 & 0.87 & -0.88 to 2.63 & 2.02 & 1.38 to 2.65 \\
\hline University degree & Ref & & Ref & & Ref & \\
\hline \multicolumn{7}{|l|}{ Survey } \\
\hline 2006 & Ref & & Ref & & Ref & \\
\hline 2010-2012 & 1.81 & 1.18 to 2.78 & 6.07 & 4.15 to 7.99 & 0.48 & -0.14 to 1.1 \\
\hline \multicolumn{7}{|l|}{ Unemployed } \\
\hline Employed & Ref & & Ref & & Ref & \\
\hline Unemployed & 1.20 & 0.77 to 1.89 & -2.1 & -4.41 to 0.21 & 0.85 & -1.14 to 1.85 \\
\hline \multicolumn{7}{|l|}{ Family type } \\
\hline Biparental & Ref & & Ref & & Ref & \\
\hline Monoparental & 1.30 & 0.95 to 1.79 & -2.28 & -4.02 to -0.55 & 1.1 & 0.41 to 1.78 \\
\hline \multicolumn{7}{|l|}{ Origin } \\
\hline Native & Ref & & & & & \\
\hline Immigrant & 1.67 & 1.28 to 2.19 & & & & \\
\hline \multicolumn{7}{|l|}{ Having breakfast } \\
\hline Sometimes/every day & Ref & & & & & \\
\hline Never & 0.94 & 0.47 to 2.18 & & & & \\
\hline Time on screen & 1.05 & 0.95 to 1.16 & & & & \\
\hline Junk food & 0.99 & 0.98 to 1.00 & & & & \\
\hline \multicolumn{7}{|l|}{ Restriction of activity (12 m) } \\
\hline No & & & Ref & & Ref & \\
\hline Yes & & & -3.01 & -5.33 to -0.69 & 0.92 & 0.07 to 1.77 \\
\hline \multicolumn{7}{|l|}{ Chronic conditions } \\
\hline No chronic conditions & & & & & Ref & \\
\hline One & & & & & 1.12 & 0.72 to 1.52 \\
\hline More than one & & & & & 2.95 & 2.39 to 3.51 \\
\hline \multicolumn{7}{|l|}{ Interaction terms } \\
\hline Primary education by survey & 0.82 & 0.45 to 1.50 & -4.14 & -7.17 to -1.12 & -1.23 & -2.29 to -0.17 \\
\hline Secondary education by survey & 0.89 & 0.54 to 1.45 & -1.6 & -3.8 to 0.66 & -1.19 & -1.99 to -0.4 \\
\hline Unemployment by survey & 1.05 & 0.61 to 1.81 & 0.07 & -2.77 to 2.93 & -0.11 & -1.02 to 1.25 \\
\hline Having breakfast by survey & 2.65 & 1.11 to -6.31 & & & & \\
\hline
\end{tabular}

caution. However, all these differences may mask even greater disparities. Moreover, the rest of the questionnaire was similar in both surveys; the data are very consistent, and the results of the study are valid and useful to analyse the impact of the crisis on child health. It is well recognised that proxy-reported weight and height may carry some bias compared with objective measures. However, there was no differential bias by educational level or any other variable analysed; hence, this does not invalidate the results regarding factors associated with overweight in children. Moreover, if other cut-off points had been used, different results in terms of percentages of overweight and obesity would have resulted. ${ }^{26}$ Finally, the duration of unemployment and whether the unemployed person was receiving a subsidy were not analysed. An analysis of these factors might enable a more in-depth examination of the impact of unemployment, and should be addressed in future studies.

The Commission on Social Determinants of Health of the WHO has proposed elimination of the health gap in one generation ${ }^{27}$ and emphasised that inequalities in early child development are one of the main factors contributing to the creation of inequalities in adult health. ${ }^{28}$ It should be noted that the living conditions of children have deteriorated and that inequalities in childhood obesity and the quality of life have increased with the crisis. It is necessary to urgently implement policy measures that fight against these inequalities. Otherwise, 
they will have a negative impact on the health of future generations of Catalans. It is also important to monitor and evaluate the impact of public policies aimed at overcoming the crisis.

Acknowledgements The authors would like to thank Pilar Brugulat, Vicenç Martinez, Josep Armengou, Laura Pellise, Cristina Colls and the ESCA i Crisi group for their contribution to this work.

Contributors LR and M-JFdS carried out the literature search. AM-B and AM-P participated in data collection. LR analysed the data. All authors participated in the study design and contributed to the data interpretation and writing of the manuscript.

Funding This research received no specific grant from any funding agency in the public, commercial or not-for-profit sectors.

Patient consent Obtained.

Provenance and peer review Not commissioned; externally peer reviewed.

Data sharing statement The data come from the Health Interview Survey of Catalonia, an official survey. We did not use any other unpublished additional data.

Open Access This is an Open Access article distributed in accordance with the Creative Commons Attribution Non Commercial (CC BY-NC 3.0) license, which permits others to distribute, remix, adapt, build upon this work noncommercially, and license their derivative works on different terms, provided the original work is properly cited and the use is non-commercial. See: http:// creativecommons.org/licenses/by-nc/3.0/

\section{REFERENCES}

1. Marcus R, Gavrilovic M. The impacts of the economic crisis on youth. Review of evidence. London: Overseas Development Institute, 2010.

2. Margerison Zilko CE. Economic contraction and birth outcomes: an integrative review. Hum Reprod Update 2010;16:445-58.

3. Dávila-Quintana CD, González López-Valcarcel B. Crisis económica y salud. Gac Sanit 2009;23:261-5.

4. Bremberg S. Does an increase of low income families affect child health inequalities? A Swedish case study. J Epidemiol Community Health 2003;57:584-8.

5. Withham G. Child poverty in 2012. It shouldn't happen here. London: Save the children, 2012.

6. Berger RP, Fromkin JB, Stutz $\mathrm{H}$, et al. Abusive head trauma during a time of increased unemployment: a multicenter analysis. Pediatrics 2011;128:637-43.

7. González-Bueno G, Bellos A, Arias M. La infancia en España 20122013. El impacto de la crisis en los niños. Madrid: UNICEF España, 2012.

8. Navarro V, Clua-Losada M. El impacto de la crisis en las familias y en la infancia. Barcelona: Observatorio social de España, 2012.

9. Direcció General de Regulació, Planificació i Recursos Sanitaris. Departament de Salut, Generalitat de Catalunya. Enquesta de salut de Catalunya 2010-2014. Fitxa técnica. Generalitat de Catalunya, 2012. http://www.gencat.catlsalutlesca

10. Departament de Salut. La salut de la població infantil a Catalunya. Enquesta de salut de Catalunya. Barcelona: Generalitat de Catalunya, Departament de Salut, Direcció General de Planificació i Avaluació, 2009

11. Mompart-Penina A, Medina-Bustos A, Guillén-Estany M, et al. Características metodológicas de la Encuesta de Salud de Cataluña 2006. Med Clin (Barc) 2011;137(Suppl 2):S3-8.

12. Serra Majem L, Aranceta Bartrina J, Pérez Rodrigo C, et al. Dossier de Consenso. Curvas de Referencia para la Tipificación Ponderal. Población Infantil y Juvenil. Madrid: IM\&C, 2002:1-83.

13. SDQ. Information for researchers and professionals about the Strengths and Difficulties Questionnaires. http://www.sdqinfo.com. (accessed 11 Jan 2013).

14. Goodman R. The Strengths and Difficulties Questionnaire: a research note. J Child Psychol Psychiatry 1997;38:581-6.

15. The KIDSCREEN Group Europe. The KIDSCREEN questionnaires. Handbook. Lengerich, Germany: Pabst Science Publishers, 2006.

16. Ravens-Sieberer U, Erhart M, Rajmil L, et al. Reliability, construct and criterion validity of the KIDSCREEN-10 score: a short measure for children and adolescents' well-being and health-related quality of life. Qual Life Res 2010;19:1487-500.

17. Flash Eurobarometer. Parents views on the mental health of their child. Analytical report. Brussels: Eurobarometer, 2009.

18. Rajmil L, Serra-Sutton V, Alonso J, et al. Validity of the Spanish version of the child health and illness profile-adolescent edition (CHIP-AE). Med Care 2003;41:1153-63.

19. Estrada MD, Rajmil L, Serra-Sutton V, et al. Reliability and validity of the Spanish version of the Child Health and Illness Profile-Child Edition Parent Report Form (CHIP-CE/PRF). Health Qual Life Outcomes 2010;8:78.

20. Institut d'Estadística de Catalunya (IDESCAT). Taxa de risc de pobresa. http://www.idescat.cat/territ/BasicTerr?TC=5\&V0 $=3 \& \mathrm{~V} 1=3 \&$ V3=1782\&V4=1839\&ALLINFO=TRUE\&PARENT=25\&CTX =B

21. Institut d'Estadística de Catalunya (Idescat). Enquesta de pressupostos familiars. http://www.idescat.cat/cat/societat/qualitat/edcl.html

22. Rajmil L, Fernandez de Sanmamed MJ. Destruction of a less developed welfare state and impact on the weakest, the youths. BM 2012. http://www.bmj.com/content/343/bmj.d7973?tab=responses

23. Rajmil L, López-Aguilà S, Mompart Penina A, et al. Socio-economic inequalities in children's mental health in Catalonia. An Pediatr (Barc) 2010;73:233-40.

24. Barriuso-Lapresa L, Hernando Arizaleta L, Rajmil L. Socia inequalities in mental health and health-related quality of life in children in Spain. Pediatrics 2012;130:e528-35.

25. Catalan Institute of Statistics (Idescat). Registration office. http:// www.idescat.catIDESCAT (accessed 21 Jun 2013).

26. Cole TJ, Bellizi MC, Flegal KM, et al. Establishing standard definition for child overweight and obesity: international survey. BMJ 2002;320:1240-3

27. World Health Organization (WHO) Commission on Social Determinants of Health. Closing the gap in a generation: health equity through action on the social determinants of health. Geneva: WHO, 2008.

28. Early Child Development Knowledge Network (ECDKN). Early child development: a powerful equalizer. Final report of the Early Child Development Knowledge Network of the Commission on Social Determinants of Health. Geneva: World Health Organization, 2007. 